\title{
Determination of drying kinetics and sorption isotherm of black pepper (Piper Nigrum)
}

\author{
Flordeliza C. De Vera ${ }^{1, *}$, Vanessa Bernadette B. Atienza ${ }^{1}$, Jomicah B. Capili ${ }^{1}$ and Zaliman Sauli ${ }^{2}$ \\ ${ }^{1}$ School of Chemical Engineering and Chemistry, Mapúa University, 658 Muralla St., Intramuros, Manila 1002, Philippines \\ ${ }^{2}$ School of Microelectronic Engineering, University Malaysia Perlis (UniMAP), Kampus Alam, Pauh Putra, 02600 Arau, Perlis, \\ Malaysia.
}

\begin{abstract}
In the present study of food products, determination of the drying characteristics of black pepper using an oven is not yet completely established. This study aimed to determine the drying kinetics and sorption isotherm of black pepper using a convective oven at $30^{\circ} \mathrm{C}, 40^{\circ} \mathrm{C}$ and $50^{\circ} \mathrm{C}$. The data gathered in this study were used to fit in selected mathematical models for drying kinetics and sorption isotherm. Among these models, the Midilli model $\left(\mathrm{MR}=0.5338 \exp \left(0.7273 \mathrm{t}^{-0.0551}\right)+-0.0005 \mathrm{t}\right.$ for $30^{\circ} \mathrm{C}$, $\mathrm{MR}=0.5814 \exp \left(0.6293 \mathrm{t}^{-0.0764}\right)+-0.0008 \mathrm{t}$ for $40^{\circ} \mathrm{C}$ and $\mathrm{MR}=0.3187 \exp \left(1.1777 \mathrm{t}^{-0.0466}\right)+-0.0011 \mathrm{t}$ for $\left.50^{\circ} \mathrm{C}\right)$ was the best fit to explain the moisture transfer in black pepper, while the GAB Model $\left.\left(\mathrm{m} / 0.1302=\left((0.1906)(0.7811) \mathrm{a}_{\mathrm{w}}\right) /\left(1-(0.7811) \mathrm{a}_{\mathrm{w}}\right)\left[1-(0.7811) \mathrm{a}_{\mathrm{w}}+(0.1906)(0.7811) \mathrm{a}_{\mathrm{w}}\right]\right)\right)$ was for the equilibrium moisture content and water activity relationship. After evaluating the data, the drying characteristics of black pepper at $40^{\circ} \mathrm{C}$ yielded better results than $30^{\circ} \mathrm{C}$ and $50^{\circ} \mathrm{C}$. XLSTAT and ANOVA Add-in of Microsoft Excel was the software used to compute for the necessary values in the assessment of the mathematical models for this study.
\end{abstract}

\section{Introduction}

Drying of food material occurs when water vapor is removed from its surface into the surrounding space, resulting in a relatively dried form of the material. The drying process as a whole has to involve the generation of vapor (transforming from the liquid phase inside the moist material to a gaseous phase) on and within the moist material being dried, and the transport of the water phases outwards of the material. Sufficient reduction of moisture content inhibits the growth of microorganisms [1]. The extent of this phenomenon can be quantified by its water activity

For centuries, people have been preserving foods to extend shelf life and protect the characteristics of food. Drying is an essential process in the post - harvest operation for spices [2]. There have been a lot of conducted researches on drying of spices such as paprika (Capsicum annum) [3], rosella flower (Hibiscus sabdariffa) and chili (Capsicum annuum) [4] because of its purpose on food application. Today, it is considered to be the king among the spices [5]. It is widely used to enhance the flavor of the foods.

There are literatures about conducted research on drying of different food products but nothing is published about drying of the fruit of black pepper in the Philippines, specifically drying using an oven drier. The Department of Agriculture (2012) has published an article but only about the varieties of black pepper, which are fitting to their respective source of origin such as Quezon, Batangas, Laguna, Zamboanga, Davao, or Basilan black pepper.

The process used on black peppercorn is still by open sun drying, which is conventional but inconvenient. This drying technique is slow, uncontrolled, exposed to environmental contamination and requires hard labor [6]. Another difficulty encountered is the drying time, since there is no proper evaluation of the moisture released with respect to time.

With so much difficulty in the traditional open sun drying, this study established the drying kinetics of black peppercorn variety from Indang, Cavite. The resulting data from the drying kinetics were used to determine the drying rate curve. The sorption isotherm was established and the models that will best fit the data were identified. Determining the sorption isotherm and drying kinetics of black peppercorn helps in the prediction of its shelf life. Other researchers can also use the resulting data and drying curves to design a better manufacturing process of black peppercorn through optimization of the present drying techniques and technologies. Thus, this can result to better quality black peppercorn and increase the efficiency of the drying equipment.

This study deals only with the drying characteristics of black peppercorn variety from Indang, Cavite. Drying will be conducted at temperatures 30,40 and 50 degrees Celsius. Drying rate, moisture content and drying time will be determined. The models that will be used for the drying kinetics are thin layer drying models of Lewis, Page, Henderson and Pabis, Two Term Exponential, and

\footnotetext{
* Corresponding author: fcdevera@mapua.edu.ph
} 
Midilli. The determination of sorption isotherm of black peppercorn will be done by gravimetric method. Results of the sorption isotherm will be analyzed using GAB and BET models. This study will not cover the effect of drying in the physical qualities such as color and texture of black peppercorn.

\section{Material and methods}

\subsection{Sample and equipment preparation}

The peppercorn, which grows in cluster, from Cavite State University was harvested and placed in clean plastic bags. The batch was washed with water to remove dirt then be laid on a paper towel to remove excess water. Using the analytical balance $(d= \pm 0.0001)$, triplicate in each proposed weight was prepared and served as trial 1, 2 and 3.

\subsection{Determination of initial moisture content (IMC or $\mathrm{MC}_{\mathrm{o}}$ )}

The IMC or $\mathrm{MC}_{\mathrm{o}}$ was determined by drying triplicate of $30 \mathrm{~g}, 40 \mathrm{~g}$ and $50 \mathrm{~g}$ samples at a temperature of $100^{\circ} \mathrm{C}$. Drying continued until the weight of the samples becomes constant.

\subsection{Drying mechanism}

In this study, Memmert UNB 400 oven was used. The oven has a mechanism of natural convection thus allows the air to circulate around the sample and distribute heat evenly. The set temperatures were $30^{\circ} \mathrm{C}, 40^{\circ} \mathrm{C}$ and $50^{\circ} \mathrm{C}$. In each temperature, a triplicate of $30 \mathrm{~g}$ sample was placed in a single layer on aluminum pans. Weighing was done with intervals of two minutes for the first ten minutes, and five minutes until the desired moisture content of $7.505 \%$ is achieved.

\subsection{Mathematical modeling of drying curves}

In general, knowledge of the mass of the samples (m) as a function of drying time $(\mathrm{t})$ allows characterizing the drying kinetics. Table 1 shows the drying curves model.

Table 1. Thin layer drying curve models.

\begin{tabular}{|l|l|}
\hline \multicolumn{1}{|c|}{ Name } & \multicolumn{1}{c|}{ Model Equation } \\
\hline Lewis & $M R=\exp (-k t)$ \\
\hline Page & $M R=\exp \left(-k t^{n}\right)$ \\
\hline Henderson \& Pabis & $M R=a \exp (-k t)$ \\
\hline Two term exponential & $M R=a \exp \left(-k_{o} t\right)+b \exp \left(-k_{1} t\right)$ \\
\hline Midilli & $M R=a \exp \left(-k t^{n}\right)+b t$ \\
\hline
\end{tabular}

\subsection{Moisture sorption isotherm}

The sorption isotherms were obtained by gravimetric method. In this method, the sample is weighed regularly at fixed pressure and temperature. Peppercorns were dried to the desired moisture content using $40^{\circ} \mathrm{C}-$ considering that its drying rate is typical compared to $30^{\circ} \mathrm{C}$ and $50^{\circ} \mathrm{C}$. The dried sample was placed in desiccators where the inside environment is controlled. Each desiccator contained a triplicate of the dried peppercorns placed in open crucibles. This method also involved the use of saturated salt solutions to maintain constant relative humidity [6].

A range of water activity was set from 0.113 to 0.806 which necessitated the use of the following salts: $\mathrm{LiCl}$, $\mathrm{MgNO}_{3}, \mathrm{KI}, \mathrm{NaCl}$ and $(\mathrm{NH} 4)_{2} \mathrm{SO}_{4}$ [7]. The salt solution volume was $1 / 4$ of the total volume of the total space for the desiccant. Salt solutions tend to loss or gain moisture when subjected to a constant temperature.

\subsection{Determination of equilibrium moisture content (EMC or $\mathrm{MC}_{\mathrm{e}}$ )}

EMC is associated with constant weighing. The weight of each sample for every salt was monitored until it became consistent.

\subsection{Mathematical modeling of sorption isotherm}

Data obtained from the gravimetric method of getting the sorption isotherm were fitted on the models found in Table 2.

Table 1. Models for Sorption Isotherm

\begin{tabular}{|c|c|}
\hline Name & $\frac{m}{M_{o}}=\frac{\text { Model Equation }}{\left(1-a_{w}\right)\left[1+(C-1) a_{w}\right]}$ \\
\hline BET & $\frac{m}{M_{o}}=\frac{C K a_{w}}{\left(1-K a_{w}\right)\left[1-K a_{w}+C K a_{w}\right]}$ \\
\hline
\end{tabular}

\subsection{Statistical method of analysis}

For the selection of drying model, drying curves were fitted to five thin layer-drying models. The suitability of the models was evaluated in terms of statistical errors coefficient of determination $\left(\mathrm{R}^{2}\right)$, mean sum of squares errors (MSE) and root mean square error (RMSE).

\section{Results and discussion}

\subsection{Drying characteristics of black pepper drying-time curve}

The drying-time curve of black pepper shows that drying time increases as temperature decreases. Heat greatly affects the drying time of black pepper but it also modifies the characteristic of black pepper, which must be considered. As shown in Figure $1,30^{\circ} \mathrm{C}, 40^{\circ} \mathrm{C}$ and $50^{\circ} \mathrm{C}$ took 2168 minutes (36 hours), 1167 minutes (19 hours) and 801 minutes (13 hours), respectively, to dry 
the black pepper up to the desired moisture content of $7.505 \%$, which is approximately $12 \mathrm{~g}$ of the final product.

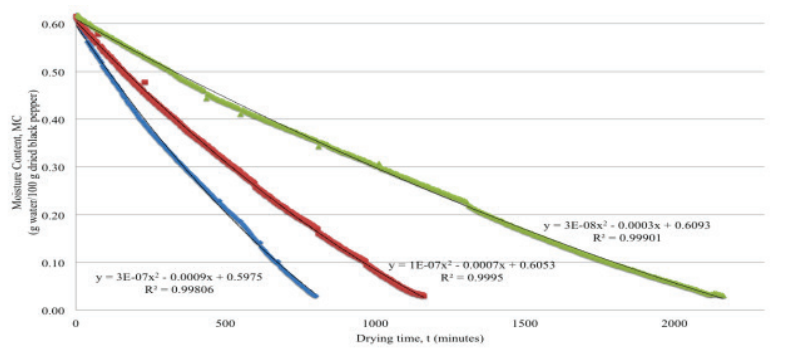

Fig. 1. Drying-time curve at $30^{\circ} \mathrm{C}$ (Green), $40^{\circ} \mathrm{C}$ (Red) and $50^{\circ} \mathrm{C}$ (Blue)

\subsection{Drying-rate curve}

Based on observation from Figure 2, there was no constant rate period thus the rate continued decreasing all throughout the drying process. Similar results were obtained for cocoa [8] and coffee [9], only falling rate period was observed both food products. For temperatures $30^{\circ} \mathrm{C}$ and $40^{\circ} \mathrm{C}$, it was noticeable that the rate was very fast at first then it slowly decreased as it proceeded. Some irregularities on drying rate were due to weighing of samples. Results were presented as the average of three trials per temperature.

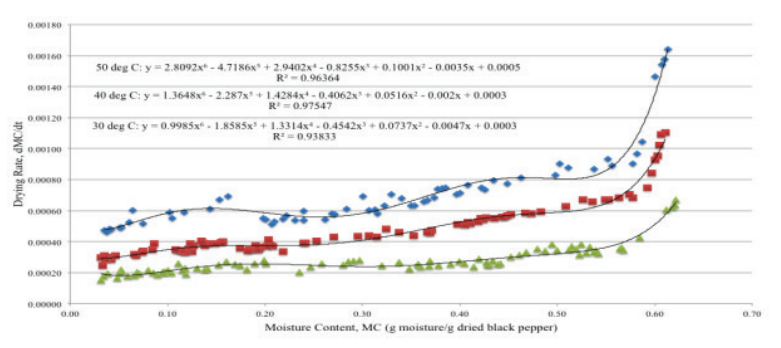

Fig. 2. Drying-rate curve at $30^{\circ} \mathrm{C}($ Green $), 40^{\circ} \mathrm{C}$ (Red) and $50^{\circ} \mathrm{C}$ (Blue)

\subsection{Mathematical modeling for drying kinetics}

Model parameters were obtained using XLStat Add -in of MS Excel by non - linear regression. These model parameters were listed in Table 3 . Table 4 shows the statistical analysis for the modeling of the moisture ratio and drying time at different temperatures for black pepper.

Table 3: Comparison of the drying models and its corresponding modeling constants at different temperatures for black pepper

\begin{tabular}{|l|l|l|l|}
\hline Model & $30^{\circ} \mathrm{C}$ & $40^{\circ} \mathrm{C}$ & $50^{\circ} \mathrm{C}$ \\
\hline Lewis & $\mathrm{k}=-0.0005$ & $\mathrm{k}=-0.0009$ & $\mathrm{k}=-0.0013$ \\
\hline Page & $\mathrm{k}=3.83 \mathrm{E}-05$ & $\mathrm{k}=0.0001$ & $\mathrm{k}=0.0007$ \\
& $\mathrm{n}=1.4737$ & $\mathrm{n}=1.4375$ & $\mathrm{n}=1.2697$ \\
\hline Henderson and & $\mathrm{a}=5.52 \mathrm{E} 07$ & $\mathrm{a}=1.0735$ & $\mathrm{a}=1.0072$ \\
Pabis & $\mathrm{k}=8.9003$ & $\mathrm{k}=0.0022$ & $\mathrm{k}=0.0034$ \\
\hline Two Term & $\mathrm{a}=0.0005$ & $\mathrm{a}=0.0006$ & $\mathrm{a}=0.0036$ \\
Exponential & $\mathrm{k}=2.0436$ & $\mathrm{k}=3.5200$ & $\mathrm{k}=0.9317$ \\
\hline
\end{tabular}

\begin{tabular}{|l|l|l|l|}
\hline Midilli & $\mathrm{a}=0.5338$ & $\mathrm{a}=0.5814$ & $\mathrm{a}=0.3187$ \\
& $\mathrm{k}=-0.7273$ & $\mathrm{k}=-0.6293$ & $\mathrm{k}=-1.1777$ \\
& $\mathrm{n}=-0.0551$ & $\mathrm{n}=-0.0764$ & $\mathrm{n}=-0.0466$ \\
& $\mathrm{~b}=-0.0005$ & $\mathrm{~b}=-0.0008$ & $\mathrm{~b}=-0.0011$ \\
\hline
\end{tabular}

Table 4: Statistical analysis for the modeling of the moisture ratio and drying time at different temperatures for black pepper

\begin{tabular}{|l|l|l|l|l|}
\hline Model & $\begin{array}{l}\text { Temperature } \\
{ }^{\circ} C\end{array}$ & $\mathrm{R}^{2}$ & RMSE & MSE \\
\hline Lewis & 30 & 0.9940 & 0.0245 & 0.0006 \\
& 40 & 0.9925 & 0.0275 & 0.0008 \\
& 50 & 0.9916 & 0.0287 & 0.0008 \\
\hline Page & 30 & 0.9734 & 0.0543 & 0.0029 \\
& 40 & 0.9755 & 0.0523 & 0.0027 \\
& 50 & 0.9532 & 0.0722 & 0.0052 \\
\hline Henderson & 30 & 0.0083 & 0.5046 & 0.2546 \\
and Pabis & 40 & 0.9505 & 0.0752 & 0.0057 \\
& 50 & 0.9407 & 0.0821 & 0.0067 \\
\hline Two Term & 30 & 0.9558 & 0.0846 & 0.0072 \\
Exponential & 40 & 0.9584 & 0.0795 & 0.0063 \\
& 50 & 0.9427 & 0.0810 & 0.0066 \\
\hline Midilli & 30 & 0.9976 & 0.0156 & 0.0002 \\
& 40 & 0.9973 & 0.0166 & 0.0003 \\
& 50 & 0.9984 & 0.0126 & 0.0002 \\
\hline
\end{tabular}

Of all the models tested, the Midilli model gave the highest value of $\mathrm{R}^{2}$ and the lowest value of RMSE and MSE for all temperatures used in the experiment, which indicates that Midilli model is suitable in describing the drying characteristics of black pepper. Same as for apple and red bell pepper [10] and for soybean [11], these foods were best described by Midilli model. From the result of ANOVA, there is no significant difference between the $\mathrm{R}^{2}$ values. Thus, the models are temperatureindependent.

\subsection{Moisture sorption curve}

The curve given on Figure 3 illustrates the relationship of the two parameters, which aids in the understanding of the water sorption properties of food. Based on Figure 3 , it is assumed that black pepper can reach the maximum equilibrium moisture content of 0.0769 , which was the average of the results of MCe of the four salts used. Conclusions on studies canola [12] and Capsicum annuum [13] state that increasing water activity leads in upward trend in value of the equilibrium moisture content. In this study, there's a sudden decrease in equilibrium moisture content at water activity value of 0.679 from 0.0987 at water activity of 0.514 . This was due to exposure to moisture during the weighing of samples. Data were presented as the average for the three trials. 


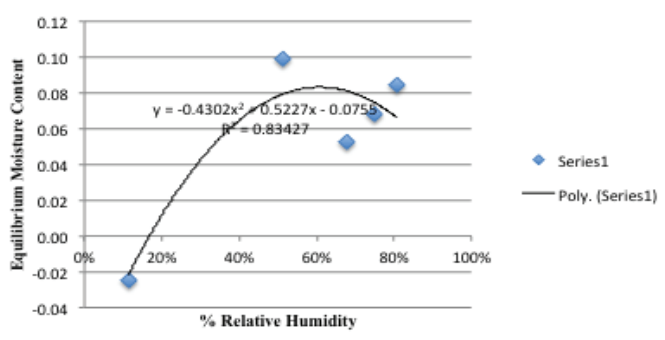

Fig. 3. EMC vs RH

\subsection{Mathematical modeling for sorption isotherm}

In this study, two models were used in predicting the sorption isotherms of black pepper, Bet and GAB model were used since these two are the most commonly used in sorption isotherms of foods [7]. Based on the statistical analysis in Table 5, GAB model has an $\mathrm{R}^{2}$ value of 0.9725 which is higher than BET. This means that GAB model is considered to be the most suitable model for describing the relation between equilibrium moisture content and water activity of black pepper. GAB was also the best model to describe the sorption isotherm of Capsicuum annuиm [13]. Table 6 shows the statistical analysis for the modeling of the moisture ratio and drying time at 40 degrees Celsius for black pepper.

Table 5.Comparison of the sorption models and its corresponding modeling parameters at 40 degrees Celsius

\begin{tabular}{|l|c|}
\hline Model & Model Parameters \\
\hline GAB & $\mathrm{Mo}=0.1302, \mathrm{C}=0.1906, \mathrm{~K}=0.7811$ \\
\hline $\mathrm{BET}$ & $\mathrm{Mo}=0.0199, \mathrm{C}=7.1097$ \\
\hline
\end{tabular}

Table 6: Statistical analysis for the modeling of the moisture ratio and drying time at 40 degrees Celsius for black pepper

\begin{tabular}{|l|l|l|l|}
\hline Model & $\mathrm{R}^{2}$ & RMSE & MSE \\
\hline GAB & 0.9725 & 0.0273 & 0.0007 \\
\hline BET & 0.4067 & 0.0519 & 0.0027 \\
\hline
\end{tabular}

\section{Conclusion}

Based on the drying kinetics of black pepper (piper nigrum) by oven drying, it was observed that the data on moisture content decreases with time and drying rate increases with increasing temperature. Also, drying time decreases as temperature increases since the heat greatly affects the evaporation of moisture to the surrounding. Moisture ratio - time relationship at temperatures $30^{\circ} \mathrm{C}$, $40^{\circ} \mathrm{C}$ and $50^{\circ} \mathrm{C}$ was described using five thin - layer model but Midilli model gave the highest $\mathrm{R}^{2}$ value of 0.9976, 0.9973 and 0.9984 for $30^{\circ} \mathrm{C}, 40^{\circ} \mathrm{C}$ and $50^{\circ} \mathrm{C}$, respectively. Midilli model also generated the lowest value of RMSE and MSE. The result indicated that Midilli model could be used to explain the moisture transfer in black pepper. Sorption curves give valuable information about the equilibrium moisture content of black pepper at different relative humidity. In this study, $\mathrm{GAB}$ and BET models were applied to fit the data.
Results confirmed that GAB model best describes the relationship of EMC - Aw of black pepper with an $\mathrm{R}^{2}$ value of 0.9725 . These data were important in storage and preservation of black pepper.

\section{References}

1. Heldman, D.R., Food Preservation Process Design, Academic Press, (2011).

2. Janjai, S. and P. Tung, Renewable Energy, Volume 30 (14), 2085-2095, (2005).

3. Ramesh, M. N., et al, Journal of Food Engineering, Volume 49 (1), 63-72, (2001).

4. Janjai, S., et al, Energy, Volume 33 (1), 91-103, (2008).

5. Jose, K. P., et al, Pertanika J. Trop. Agri. Sci., Volume 25 (1), 39-45, (2002).

6. Raji, A. O., \& Ojediran, J. O., Food and bioproducts processing, 89(3), 178-184, (2011).

7. Chen, H. H., Huang, T. C., Tsai, C. H., \& Mujumdar, A. S., Drying Technology, 26(4), 503507, (2008).

8. Chinenye N.M., et al., Chilean Journal of Agricultrural Research, Volume 70(4), 633-639, (2010).

9. Correa, P.C., et al, Drying Characteristics and Kinetics of Coffee Berry. Revista Brasileira de Produtos Agroindustriais, Campina Grande, v.8, n.1, p.1-10, (2006).

10. Schössler, K., Jäger, H., \& Knorr, D., Journal of Food Engineering, 108 (1), 103-110, (2012).

11. Rafiee, S., Keyhani, A., Sharifi, M., Jafari, A., Mobli, H., \& Tabatabaeefar, A., J. Agr. Sci. Tech, 11, 289-300, (2009)..

12. Zare D. et al., Iran Agricultural Research, Vol. 30, No.1, 2, (2011) \& Vol. 31, No.1, (2012).

13. Akin, A., et al., GIDA 34 (4): 205-211, (2009). 